\title{
Penanganan Fuzzy Time Window pada Travelling Salesman Problem (TSP) dengan Penerapan Algoritma Genetika
}

\author{
Gusti Eka Yuliastuti, Wayan Firdaus Mahmudy, Agung Mustika Rizki
}

\begin{abstract}
The route of the travel tour packages offered by travel agents is not considered optimum, so the level of satisfaction the tourist is not maximal. Selection of the route of the travel packages included in the traveling salesman problem (TSP). The problem that occurs is uncertain tourists visiting destinations at the best destinations timing hereinafter be referred to as the fuzzy time window problem. Therefore, the authors apply the genetic algorithm to solve the problem. Based on test results obtained optimum solution with the fitness value of 1.3291, a population size of 100 , the number of generations of 1000, a combination of $C R=0,4$ and $M R=0.6$.
\end{abstract}

Index Terms-Travel Route, Travel Destination, Travelling Salesman Problem (TSP), Fuzzy Time Window

\begin{abstract}
Abstrak-- Rute perjalanan paket wisata yang ditawarkan oleh biro perjalanan wisata dinilai tidak optimum sehingga tingkat kepuasan wisatawan tidak maksimal. Pemilihan rute perjalanan paket wisata tersebut termasuk dalam travelling salesman problem (TSP). Permasalahan yang terjadi adalah ketidakpastian atau tidak tepatnya wisatawan berkunjung ke destinasi pada waktu terbaik destinasi tersebut yang selanjutnya dapat disebut sebagai permasalahan fuzzy time window. Oleh karena itu penulis menerapkan algoritma genetika guna menyelesaikan permasalahan tersebut. Berdasarkan hasil pengujian didapatkan solusi optimum dengan nilai fitness sebesar 1,3291 dengan ukuran populasi sebesar 100, jumlah generasi sebanyak 1000 serta kombinasi $\mathrm{CR}=0,4$ dan $\mathrm{MR}=0,6$.
\end{abstract}

Kata Kunci-Rute Perjalanan, Destinasi Wisata, Travelling Salesman Problem (TSP), Fuzzy Time Window

This work was supported in part by Computer Science Department of Brawijaya University, Malang, Indonesia.

Gusti Eka Yuliastuti was with Computer Science Department of Brawijaya University, Malang, Indonesia. (corresponding author email gustiekay@gmail.com).

Wayan Firdaus Mahmudy was with Computer Science Department of Brawijaya University, Malang, Indonesia. (corresponding author emailwayanfm@ub.ac.id).

Agung Mustika Rizki was with Computer Science Department of Brawijaya University, Malang, Indonesia. (corresponding author email agungmustikarizki@gmail.com).

\section{Pendahuluan}

B anyaknya destinasi wisata di kota Malang, menjadi keuntungan tersendiri bagi para biro perjalanan wisata. Biro perjalanan wisata (BPW) merupakan usaha penyediaan jasa perencanaan dan / atau jasa pelayanan dan penyelenggaraan wisata [1]. Beberapa rute perjalanan paket wisata yang ditawarkan oleh BPW tersebut tidak optimum dan sangat berpengaruh dengan tingkat kepuasan wisatawan. Ketidakoptimuman terjadi dikarenakan tidak dapat memanfaatkan waktu semaksimal mungkin untuk mengunjungi beberapa destinasi dan tentu saja batasan waktu permasalahan seperti ini dapat disebut sebagai travelling salesman problem (TSP). Batasan waktu pada destinasi ini bukanlah hanya mengenai waktu operasional, namun lebih kepada rekomendasi waktu kunjung terbaik. Jika berkunjung ke suatu destinasi dalam waktu terbaik tersebut tentu saja akan menambah tingkat kepuasan wisatawan. Namun saat penjadwalan rute destinasi wisata, tidak menutup kemungkinan jika mendapatkan waktu diluar waktu terbaik tersebut. Ketidakpastian waktu ini selanjutnya disebut sebagai masalah fuzzy time window.

Pentingnya permasalahan ini untuk diselesaikan karena bukan hanya perihal pencarian rute terpendek namun juga mempertimbangkan batasan yag ada. Beberapa penelitian sebelumnya menyelesaikan TSP dengan batasan antara lain handling cost[2], deadline and advanced information[3], dependent service time [4], fuzzy constraint [5] dan time window [6]-[10] juga termasuk fuzzy dalam time window tersebut [11].

Terdapat beberapa metode yang dapat diterapkan dalam menyelesaikan TSP diantaranya Ant Colony Optimization (ACO) [5][12], Campbell Dudeck Smith (CDS), Greedy Algorithm [9][13], Particle Swarm Optimization (PSO) [14][15], dan Genetic Algorithm (Algoritma Genetika) [16]-[19].

Dalam permasalahan ini penulis menerapkan algoritma genetika karena algoritma ini tidak menghasilkan solusi tunggal namun menghasilkan banyak kombinasi solusi untuk mendapatkan solusi yang mendekati optimum. 


\section{STUdi LiterAtUR}

Dalam menyelesaikan permasalahan TSP ini, terdapat beberapa metode yang dapat diterapkan. Chen dan Chien [15] melakukan penelitian untuk menyelesaikan permasalahan TSP dengan menerapkan metode ACO. Setelah dilakukan percobaan menggunakan data set yang berasal dari TSPLIB, mereka mengklaim bahwa metode ACO lebih baik dibandingkan metode Angeniol karena hasil percobaan menunjukkan solusi rata-rata untuk mendapatkan nilai optimum tersebut lebih baik dengan menerapkan ACO. Terdapat juga penelitian sebelumnya yang menerapkan metode ACO yakni penelitian yang dilakukan oleh Dong, Guo dan Tickle [12]. Namun terdapat perbedaan dibandingkan Chen dan Chien. Dalam penelitian ini, mereka melakukan hibridisasi metode antara ACO dan algoritma genetika. Fungsi dari algoritma genetika itu sendiri untuk meningkatkan kinerja metode ACO dalam menyelesaikan permasalahan TSP.

Saptaningtyas [20] melakukan penelitian mengenai pengelolaan rute destinasi wisata dengan menerapkan metode CDS. Fungsi dari metode CDS ini adalah untuk membuat jadwal kunjungan pada destinasi wisata agar tidak menumpuk. Optimasi yang dilakukan adalah dengan meminimalkan total waktu kunjungan dan meminimalkan waktu tunggu.

Karabulut dan Tasgetiren [9] menerapkan algoritma Greedy untuk memecahkan permasalahan TSP dengan time window. Hasil percobaan membuktikan bahwa dengan menerapkan Greedy ini didapatkan hasil lebih baik.

Terdapat pula metode lain yang diterapkan oleh Yau dan Chen [14] yakni metode PSO. Permasalahan TSP dalam penelitian ini dapat diselesaikan lebih efisien dengan menerapkan metode PSO.

Metode terakhir yang juga dapat diterapkan untuk menyelesaikan permasalahan TSP adalah algoritma genetika. Widodo dan Mahmudy [19] melakukan penelitian untuk rekomendasi kuliner. Pada studi kasus dalam penelitian ini, didapatkan solusi optimum dengan tidak hanya mencari jarak terpendek namun juga mencocokkan pilihan destinasi wisata, selera dalam hal pemilihan tempat makan dan juga waktu perjalanan. Sedangkan Setiawan dan Pinandito [17] dalam penelitiannya untuk penjadwalan objek wisata, juga menerapkan algoritma genetika. Namun dalam pencarian solusinya, mereka tidak memperhatikan time window. Time window merupakan suatu hal yang sangat penting karena dapat berpengaruh pada nilai fitness dari suatu solusi. Berdasarkan kepentingan itulah, Suprayogi dan Mahmudy [18] melakukan penelitian TSP dengan contoh kasus rute untuk antar jemput laundry. Pada contoh kasus tersebut, terdapat waktu ketersediaan pelanggan yang berbedabeda kemudian hal tersebut dijadikan batasan menjadi time window. Dengan kombinasi probabilitas terbaik, dihasilkan solusi mendekati optimum yang memungkinkan petugas untuk antar jemput laundry pada time window masing-masing pelanggan.

Dari beberapa penelitian yang pernah dilakukan sebelumnya, membuktikan bahwa penerapan algoritma genetika menghasilkan solusi lebih baik dibandingkan metode lainnya karena solusi tersebut berasal dari berbagai kombinasi solusi hasil evolusi. Sehingga penulis memilih algoritma genetika untuk diterapkan dalam penanganan fuzzy time window pada permasalahan TSP.

\section{TRAVELLING SALESMAN PROBLEM}

Permasalahan TSP ini merupakan salah satu permasalahan yang bertujuan untuk mencari jarak terpendeknya dari beberapa titik yang dikunjungi [15]. Dimana setiap titik yang dikunjungi tersebut hanya boleh satu kali saja dan kembali ke titik awal [19][21]. Pada penelitian ini permasalahan TSP yang diselesaikan adalah penjadwalan rute paket wisata, yakni terdapat 27 destinasi wisata populer di kota Malang yang perlu dijadwalkan dengan baik selama 3 hari.

\section{FuZZY TIME WINDOW}

Time window merupakan salah satu tambahan variabel dalam parameter sebagai batasan permasalahan TSP [21]. Sedangkan fuzzy time window merupakan salah satu modifikasi dari time window. Maksud dari fuzzy ini sendiri adalah ketidakpastian. Pada penelitian ini ketidakpastian waktu yang dimaksud adalah waktu kunjungan terbaik dari setiap destinasi pada interval waktu tertentu. Sebagai contoh, Wisata Paralayang Gunung Banyak sangat indah pemandangannya apabila wisatawan berkunjung pada waktu terbaiknya yakni kurang dari pukul 07.00 WIB untuk melihat terbitnya matahari dan jika melebihi pukul 13.00 WIB teriknya matahari sangat menyengat sehingga tidak direkomendasikan untuk berkunjung. Terdapat interval waktu antara pukul 07.00 WIB hingga pukul 13.00 WIB. Jika wisatawan berkunjung pada interval waktu tersebut terjadilah ketidakpastian fungsi keanggotaan waktu kunjungan terbaik. Untuk memudahkan perhitungan penalty, maka penulis membuat 9 bagian waktu mulai dari pukul 05.00 hingga pukul 23.00 dengan interval sebesar 2 jam, seperti berikut:

Tabel 1. Bagian Waktu

\begin{tabular}{ccc}
\hline \hline Bagian Waktu & Batas Atas & Batas Bawah \\
\hline 1 & 05.00 & 07.00 \\
2 & 07.00 & 09.00 \\
3 & 09.00 & 11.00 \\
4 & 11.00 & 13.00 \\
5 & 13.00 & 15.00 \\
6 & 15.00 & 17.00 \\
7 & 17.00 & 19.00 \\
8 & 19.00 & 21.00 \\
9 & 21.00 & 23.00 \\
\hline \hline
\end{tabular}

Dari permasalahan tersebut, dapat dimodelkan fungsi dan derajat keanggotaan fuzzy dari salah satu destinasi sebagai contoh yakni Wisata Paralayang Gunung Banyak berdasarkan waktu kunjung terbaiknnya sebagai berikut: 


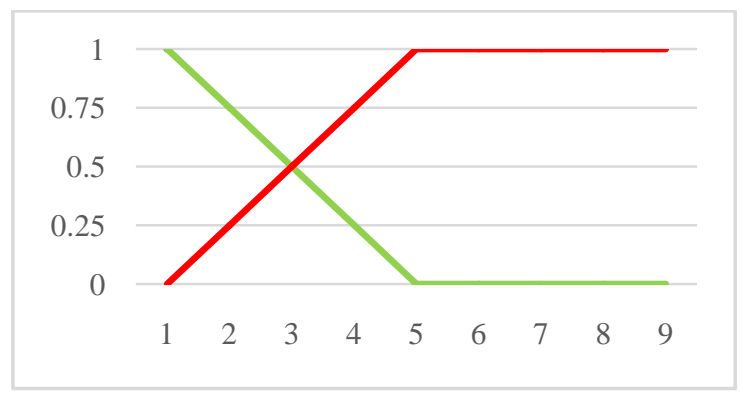

Gambar 1Contoh Fuzzy Time Window

Keterangan:

Waktu baik untuk berkunjung

Waktu buruk untuk berkunjung

Waktu Kunjungan Terbaik $\left\{\begin{array}{c}1, \text { tiba } \leq 1 \\ \frac{5-t i b a}{5-1}, \text { lainnya } \\ 0, \text { tiba }>5\end{array}\right.$

Contoh perhitungan fungsi keanggotaan destinasi Wisata Paralayang Gunung Banyak jika wisatawan datang pada bagian waktu 4 adalah sebagai berikut:

$$
\text { Waktu Kunjungan Terbaik }=\frac{5-4}{5-1}=\frac{1}{4}=0,25
$$

Didapatkan fungsi keanggotaan waktu kunjungan terbaik untuk Wisata Paralayang Gunung Banyak sebesar 0,25. Sehingga perhitungan penalty pada destinasi tersebut dapat dicari dengan rumusan sebagai berikut:

$$
\text { Penalty }=1-F(\text { kunjunganTerbaik })
$$

Sehingga penalty untuk destinasi tersebut jika wisatawan tiba pada bagian waktu 4 adalah sebesar 0,75 .

\section{AlgORITMA GENETIKA}

Algoritma genetika merupakan teknik optimasi yang memiliki dasar teori evolusi [16][19][21][22]. Alur pencarian solusi dengan algoritma genetika ini adalah dengan menampung semua solusi pada suatu populasi untuk didapatkan solusi yang terbaik pada generasi tertentu berdasar nilai fitness. Berikut tahapan dalam algoritma genetika [22].

\section{a. Representasi Kromosom}

Terdapat istilah kromosom pada algoritma genetika yang berarti representasi solusi dari permasalahan. Dalam penelitian ini digunakan representasi kromosom permutasi. Contoh kromosomnya yakni sebagai berikut:

\begin{tabular}{|l|l|l|l|l|l|l|l|l|}
\hline 2 & 4 & 6 & 8 & 1 & 3 & 5 & 7 & 9 \\
\hline
\end{tabular}

Setiap gen dalam 1 baris kromosom tersebut berarti destinasi wisata, sehingga jika dibaca secara keseluruhan membentuk suatu rute perjalanan tertentu. Jika kromosom tersebut diartikan untuk rute perjalanan wisata menjadi destinasi 2 akan dikunjungi pertama kemudian mengunjungi destinasi 4 dan begitu seterusnya.

b. Proses Inisialisasi

Proses inisialisasi merupakan tahapan awal pembangkitan parent secara random sejumlah popSize yang telah ditentukan[23]. Dalam penelitian ini, peneliti akan melakukan pengujian untuk mendapatkan popSize optimum. Berikut contoh inisialisasi populasi awalnya:

Tabel 2Contoh Inisialisasi Populasi Awal

\begin{tabular}{cccccccccc}
\hline \hline I & \multicolumn{10}{c}{ Kromosom } \\
\hline P1 & 2 & 4 & 6 & 8 & 1 & 3 & 5 & 7 & 9 \\
P2 & 1 & 4 & 7 & 2 & 5 & 8 & 3 & 6 & 9 \\
P3 & 9 & 8 & 6 & 5 & 3 & 2 & 1 & 4 & 7 \\
P4 & 5 & 7 & 4 & 2 & 1 & 3 & 6 & 9 & 8 \\
$\ldots$ & $\ldots$ & $\ldots$ & $\ldots$ & $\ldots$ & $\ldots$ & $\ldots$ & $\ldots$ & $\ldots$ & $\ldots$ \\
\hline \hline
\end{tabular}

Kromosom diatas merupakan inisialisasi random pada populasi awal.

\section{c. Proses Reproduksi}

Proses reproduksi dilakukan dengan tujuan untuk menghasilkan keturunan (offspring) [22]. Dalam algoritma genetika, terdapat 2 cara menghasilkan offspring yaitu: metode pindah silang (crossover)dan mutasi (mutation). Pada crossover dibutuhkan 2 kromosom sebagai parent untuk dipindah silang, sedangkan pada mutasi hanya perlu 1 kromosom sebagai parent. Berikut adalah contoh child hasil reproduksi.

\begin{tabular}{|c|c|c|c|c|c|c|c|c|c|}
\hline$\overline{I I}$ & \multicolumn{9}{|c|}{ Kromosom } \\
\hline P1 & 2 & 4 & 6 & 8 & 1 & 3 & 5 & 7 & 9 \\
\hline P2 & 1 & 4 & 7 & 2 & 5 & 8 & 3 & 6 & 9 \\
\hline C1 & 2 & 4 & 6 & 8 & 1 & 7 & 5 & 3 & 9 \\
\hline
\end{tabular}

Tabel 3. Contoh Crossover

Crossover menggunakan teknik one-cut-point pada titik perpotongan ke-4.

Tabel 4 Contoh Mutasi

\begin{tabular}{cccccccccc}
\hline \hline I & \multicolumn{10}{c}{ Kromosom } \\
\hline P3 & 9 & 8 & 6 & 5 & 3 & 2 & 1 & 4 & 7 \\
C2 & 8 & 6 & 5 & 3 & 2 & 1 & 4 & 7 & 9 \\
\hline \hline
\end{tabular}

Mutasi menggunakan teknik insertion di akhir, sehingga setiap gen dalam kromosom akan bergeser ke kiri dan gen paling awal akan pindah ke paling akhir.

d. Proses Evaluasi

Proses evaluasi ini dilakukan untuk menilai baik dan buruknya sebuah kromosom. Cara menilai baik dan buruknya sebuah kromosom adalah dengan menghitung nilai fitnessnya[23]. Dalam penelitian ini rumusan dalam menghitung nilai fitness adalah sebagai berikut: 
Nilai Fitness $=\frac{100}{J T+W T+\left(\sum P \times 60\right)}$

JT (Jarak Tempuh) $\rightarrow$ jumlah dari jarak keseluruhan destinasi yang dikunjungi kemudian ditambahkan dengan jarak dari start point menuju destinasi pertama dan jarak dari destinasi terakhir menuju start point.

WT (Waktu Tempuh) $\rightarrow$ waktu yang diperlukan untuk menuju destinasi tersebut.

$\mathrm{P}$ (Penalty) $\rightarrow$ pelanggaran yang dihitung dari fungsi keanggotaan waktu kunjungan terbaik pada interval bagian waktu tertentu.

Berikut adalah contoh perhitungan nilai fitness untuk $\mathrm{C} 1$.

$$
\text { Nilai Fitness } \begin{aligned}
C 1 & =\frac{100}{52,30+62,76+(9 \times 60)} \\
& =0,15058
\end{aligned}
$$

\section{e. Proses Seleksi}

Proses seleksi ini adalah pemilihan kromosom terbaik sebanyak ukuran populasi (popSize) yang ditentukan diawal. Proses seleksi dalam penelitian ini menggunakan metode seleksi elitism yakni memilih kromosom terbaik sejumlah popSize untuk dijadikan parent pada generasi berikutnya [22].

\section{PEnguJian}

Terdapat 3 skenario pengujian dalam penelitian ini, yakni sebagai berikut:

a. Pengujian ukuran populasi untuk menghasilkan solusi optimum.

b. Pengujian jumlah generasi untuk menghasilkan solusi optimum.

c. Pengujian kombinasi Crossover Rate (CR) dan Mutation Rate (MR) untuk menghasilkan solusi optimum.

\section{ANALISIS HASIL PENGUJIAN}

a. Dalam pengujian ukuran populasi ini, penulis menggunakan generasi sejumlah 100 serta kombinasi $\mathrm{CR}=0,5$ dan $\mathrm{MR}=0,5$. Setiap kali pengujian dilakukan sebanyak 10 kali kemudian dihitung rata-ratanya.

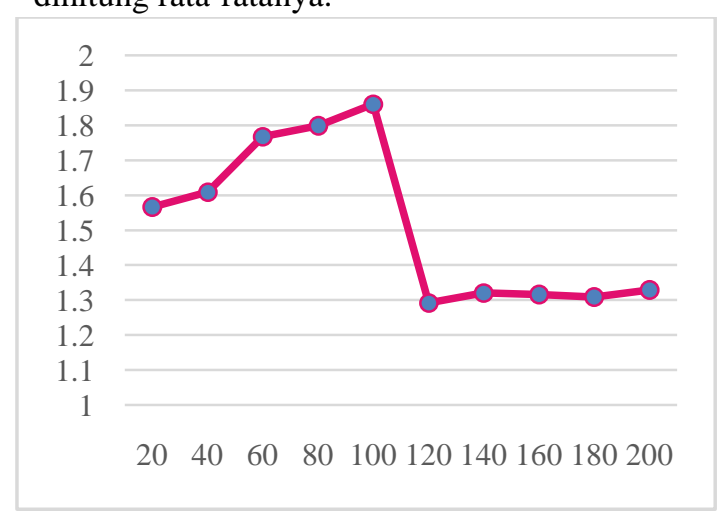

Gambar 3 Hasil Pengujian Jumlah Populasi
Dapat dilihat pada grafik, terdapat titik tertitinggi pada ukuran populasi sebesar 100 dengan nilai fitness sebesar 1,8607 .

b. Dalam pengujian jumlah generasi, penulis menggunakan ukuran populasi sebesar 100 serta kombinasi $\mathrm{CR}=0,5$ dan $\mathrm{MR}=0,5$. Setiap kali pengujian dilakukan sebanyak 10 kali kemudian dihitung rata-ratanya.

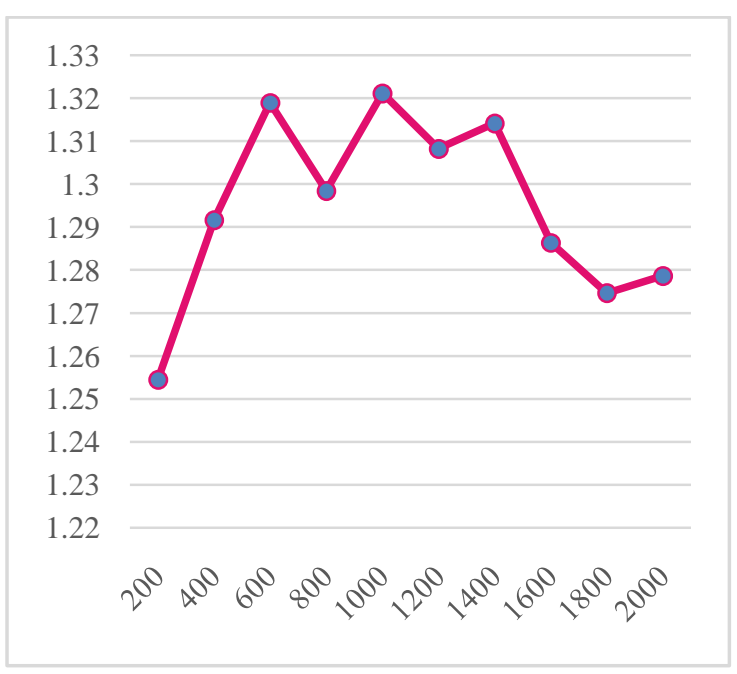

Gambar 4.Hasil Pengujian Jumlah Generasi

Dapat dilihat pada grafik, terdapat titik tertinggi pada generasi sejumlah 1000dengan nilai fitness sebesar 1,3211 .

c. Dalam pengujian kombinasi CR dan MR, penulis menggunakan data yang sudah didapat dari pengujian sebelumnya yakni ukuran populasi sebesar 100 dan generasi sejumlah 1000 juga. Setiap kali pengujian dilakukan sebanyak 10 kali kemudian dihitung rata-ratanya. Penulis menggunakan 11 kombinasi antara $0-1$, dapat dilihat pada tabel berikut:

Tabel 5. Kombinasi CR dan MR

\begin{tabular}{ccc}
\hline \hline Kombinasi & CR & MR \\
\hline 1 & 0 & 1 \\
2 & 0,1 & 0,9 \\
3 & 0,2 & 0,8 \\
4 & 0,3 & 0,7 \\
5 & 0,4 & 0,6 \\
6 & 0,5 & 0,5 \\
7 & 0,6 & 0,4 \\
8 & 0,7 & 0,3 \\
9 & 0,8 & 0,2 \\
10 & 0,9 & 0,1 \\
11 & 1 & 0 \\
\hline \hline
\end{tabular}




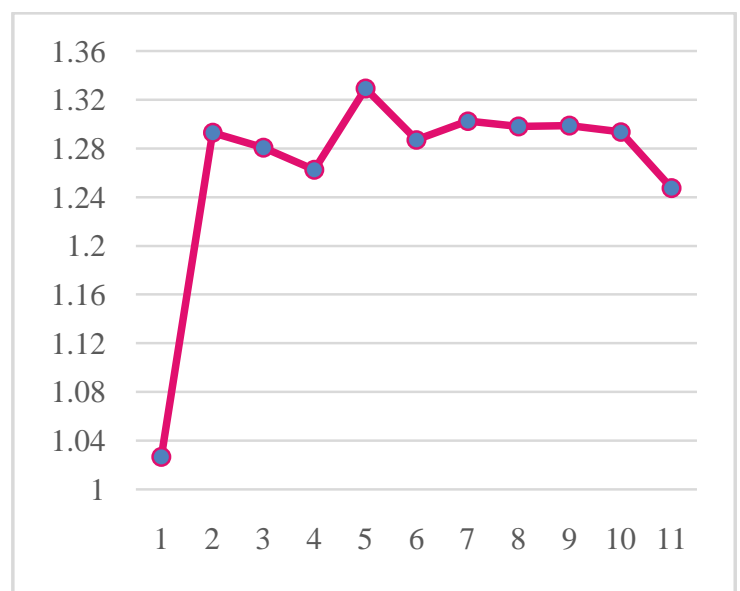

Gambar 5Hasil Pengujian Kombinasi CR dan MR

Dapat dilihat pada grafik, terdapat titik tertitinggi pada kombinasi 5 yakni $\mathrm{CR}=0,4$ dan $\mathrm{MR}=0,6$ dengan nilai fitness sebesar 1,3291 .

\section{KESIMPULAN}

Dari hasil pengujian serta analisis maka didapatkan kesimpulan sebagai berikut:

a. Ukuran populasi untuk menghasilkan solusi optimum adalah sebesar 100 dengan nilai fitness 1,8607 .

b. Jumlah generasi untuk menghasilkan solusi optimum adalah sejumlah 1000 dengan nilai fitness 1,3211 .

c. KombinasiCR dan MR untuk menghasilkan solusioptimum adalah $\mathrm{CR}=0,4$ dan $\mathrm{MR}=0,6$.

\section{DAFTAR PUSTAKA}

[1] D. Komisioner and O. Jasa, Undang-undang Republik Indonesia Nomor 9 Tahun 1990 Tentang Kepariwisataan. 1990, pp. 1-10.

[2] M. Veenstra, K. J. Roodbergen, I. F. A. Vis, and L. C. Coelho, "The pickup and delivery traveling salesman problem with handling cost," vol. 257, no. September, pp. 118-132, 2015.

[3] X. Wen, Y. Xu, and H. Zhang, "Computers \& Industrial Engineering Online traveling salesman problem with deadline and advanced information," vol. 63, pp. 1048-1053, 2012.

[4] D. Taş, M. Gendreau, O. Jabali, and G. Laporte, "The traveling salesman problem with timedependent service times," Eur. J. Oper. Res., vol. 248, no. 2, pp. 372-383, 2016.

[5] J. Brito, F. J. Martínez, J. A. Moreno, and J. L. Verdegay, "An ACO hybrid metaheuristic for close - open vehicle routing problems with time windows and fuzzy constraints," Appl. Soft Comput. J., vol. 32, pp. 154-163, 2015.

[6] I. Kara and T. Derya, "Formulations for Minimizing Tour Duration of the Traveling Salesman Problem with Time Windows," Procedia Econ. Financ., vol. 26, no. 15, pp. 1026-1034, 2015.

[7] Y.-Y. Chen, "Fuzzy Flexible Delivery and Pickup Problem with Time Windows,"
Procedia Comput. Sci., vol. 17, pp. 379-386, 2013.

[8] R. Roberti and M. Wen, "The Electric Traveling Salesman Problem with Time Windows," Transp. Res. Part E Logist. Transp. Rev., vol. 89, pp. 32-52, 2016.

[9] K. Karabulut and M. Fatih Tasgetiren, "A variable iterated greedy algorithm for the traveling salesman problem with time windows," Inf. Sci. (Ny)., vol. 279, pp. 383-395, 2014.

[10] N. Mladenović, R. Todosijević, and D. Urošević, "An efficient GVNS for solving Traveling Salesman Problem with Time Windows," Electron. Notes Discret. Math., vol. 39, pp. 83-90, 2012.

[11] S. F. Ghannadpour, S. Noori, R. TavakkoliMoghaddam, and K. Ghoseiri, "A multiobjective dynamic vehicle routing problem with fuzzy time windows: Model, solution and application," Appl. Soft Comput., vol. 14, pp. 504-527, 2014.

[12] G. Dong, W. W. Guo, and K. Tickle, "Solving the traveling salesman problem using cooperative genetic ant systems," Expert Syst. Appl., vol. 39, no. 5, pp. 5006-5011, 2012.

[13] X. Geng, Z. Chen, W. Yang, D. Shi, and K. Zhao, "Solving the traveling salesman problem based on an adaptive simulated annealing algorithm with greedy search," Appl. Soft Comput. J., vol. 11, no. 4, pp. 3680-3689, 2011.

[14] Y. F. Liao, D. H. Yau, and C. L. Chen, "Evolutionary algorithm to traveling salesman problems," Comput. Math. with Appl., vol. 64, no. 5, pp. 788-797, 2012.

[15] S.-M. Chen, C.-Y. Chien, S.-M. Chena, and C.Y. Chiena, "Solving the traveling salesman problem based on the genetic simulated annealing ant colony system with particle swarm optimization techniques," Expert Syst. Appl., vol. 38, no. 12, pp. 14439-14450, 2011.

[16] S. Maity, A. Roy, and M. Maiti, "A Modified Genetic Algorithm for solving Uncertain Constrained Solid Travelling Salesman Problems," Comput. Ind. Eng., vol. 83, pp. 273296, 2015.

[17] B. D. Setiawan and A. Pinandito, "Optimasi Kunjungan Objek Wisata dengan Menggunakan Algoritma Genetik," in Prosiding Seminar Nasional Teknologi dan Rekayasa Informasi 2016, 2016, p. 71.

[18] D. A. Suprayogi, W. F. Mahmudy, and M. T. Furqon, "Penerapan Algoritma Genetika Traveling Salesman Problem with Time Window: Studi Kasus Rute Antar Jemput Laundry," J. Buana Inform., pp. 1-8, 2014.

[19] A. W. Widodo and W. F. Mahmudy, "Penerapan Algoritma Genetika pada Sistem Rekomendasi Wisata Kuliner," J. Ilm. Kursor, vol. 5, no. 4, pp. 205-211, 2010.

[20] F. Y. Saptaningtyas, "Optimasi Pengelolaan Pariwisata di DIY dengan Menggunakan Metode Campbell Dudeck Smith (CDS)," no. 
November, pp. 978-979, 2013.

[21] N. D. Priandani and W. F. Mahmudy, "Optimasi Travelling Salesman Problem With Time Windows ( Tsp-Tw ) Pada Penjadwalan Paket Rute Wisata," Semin. Nas. Sist. Inf. Indones., no. November, pp. 2-3, 2015.

[22] U. Brawijaya, "DASAR-DASAR Algoritma Evolusi," 2016
[23] M. A. Yaqin and T. Lisbiantoro, "Optimasi Penjadwalan Perkuliahan Jurusan Teknik Informatika Universitas Islam Negeri Maulana Malik Ibrahim Malang Menggunakan Algoritma Genetika dengan Metode Seleksi Rank," MATICS J. Ilmu Komput. dan Teknol. Inf., vol. 4, no. 5, pp. 191-196, 2012. 